\title{
Original Paper / Artigo Original \\ Phenological study of populations of Cnidoscolus quercifolius in the Western Seridó, Paraiba state, Brazil
}

\author{
Érica Caldas S. de Oliveira ${ }^{1,5}$, Everaldo O. Costa Júnior ${ }^{2}$, Pedro D. Fernandes ${ }^{3}$ \& Zelma Glebya M. Quirino ${ }^{4}$
}

\begin{abstract}
The phenological patterns of two populations of Cnidoscolus quercifolius were evaluated in the western Seridó region of Paraiba state, Brazil, from March 2009 to February 2011, with data collected monthly. The evaluations have addressed the quantitative method of analysis that represents the activity indices for both populations growing seasons (fall and sprout) and reproductive (flowering and fruiting), and also studied the intensity index Borchert, who evaluated the flow leaves. The stages were evaluated with respect to variations in rainfall, water potential of plant and quantum efficiency of photosystem II. The bud in the two populations occurred in the late dry season and transition into the rainy season, with peak leafing in January and November 2010 and was negatively correlated with rainfall ( $r s=-0.54 p<0.05$ ). Leaf fall showed the peak phase in October 2009 and 2010, showing a direct relationship with water potential and photosynthetic quantum efficiency. The flowering and fruiting had greater synchrony in the seasonal rainy period, fruit set was positively correlated with precipitation values during the study period ( $\mathrm{rs}=0.56 \mathrm{p}<0.05$ ). The phenological events of C. quercifolius show marked seasonality in relation to precipitation, water potential and the quantum efficiency of photosystem II.
\end{abstract}

Key words: Euphorbiaceae, phenology, semiarid.

\section{Resumo}

Padrões fenológicos de duas populações de Cnidoscolus quercifolius foram avaliados em área de caatinga no Seridó Ocidental, estado da Paraíba, Brasil, no período de março de 2009 a fevereiro de 2011, com dados coletados mensalmente. As avaliações abordaram uma análise quantitativa dos índices de atividade em períodos vegetativo (brotamento e queda) e reprodutivo (floração e frutificação), analisou-se também o índice de intensidade de Borchert, que avaliou o fluxo foliar. As fenofases foram avaliadas em relação a variações de precipitação, potencial de água na planta e fotossistema II. O brotamento ocorreu no fim da estação seca e transição para a estação chuvosa, com pico dessa fenofase em janeiro e novembro de 2010, sendo negativamente correlacionado com a precipitação ( $\mathrm{rs}=-0,54 \mathrm{p}<0,05)$. A queda apresentou pico em outubro de $2009 \mathrm{e}$ 2010, mostrando uma relação direta com o potencial hídrico e eficiência quântica fotossintética. A floração e frutificação tiveram maior sincronia no período de chuvas, a frutificação foi positivamente correlacionada com valores de precipitação durante o período de estudo ( $\mathrm{rs}=0,56 \mathrm{p}<0,05)$. Os eventos fenológicos de $C$. quercifolius revelaram marcada sazonalidade em relação à precipitação, o potencial da água e da eficiência quântica do fotossistema II.

Palavras-chave: Euphorbiaceae, fenologia, semiárido.

\footnotetext{
${ }^{1}$ Universidade Estadual da Paraiba, Dep. Biology, Av Baraunas 351 Campus Bodocongó, 58109-753, Campina Grande, PB, Brazil.

${ }^{2}$ Universidade Federal da Paraíba, Campus IV, Mamanguape, Rio Tinto, Fábrica de Tecidos Rio Tinto, R. da Mangueira s/n, Centro, 58297-000 , Rio Tinto, PB, Brazil.

${ }^{3}$ Universidade Federal de Campina Grande, Dep. Agricultural Engineering, R. Aprígio Veloso 882, Bairro Universitário, 58429-140, Campina Grande, PB, Brazil.

${ }^{4}$ Universidade Federal da Paraíba, Dep. Engineering and Environmental, Campus IV, Mamanguape, Rio Tinto, Fábrica de Tecidos Rio Tinto, R. da Mangueira $\mathrm{s} / \mathrm{n}$, Centro, 58297-000, Rio Tinto, PB, Brazil.

${ }^{5}$ Corresponding author: erica.caldas_8@hotmail.com
} 


\section{Introduction}

Phenological studies are essential to our understanding of the dynamics of plant growth and response to environmental factors, especially precipitation, water stress, solar irradiation, and photoperiod in their native ecosystems.

In the caatinga (dry land) and tropical semiarid forest, phenological studies are important to consolidate our knowledge of this region and to developing strategies for the sustainable use of its biological resources.

Phenological research projects at the community and species levels in the semiarid tropics have contributed greatly to our understanding of the adaptive aspects of the plants occupying these complex biomes, characterized by climatic extremes and high degrees of endemism (Pereira et al. 1989; Barbosa et al. 1989, 2003; Vogel \& Machado 1991; Locatelli \& Machado 1999a,b; Quirino \& Machado 2001; Machado et al. 1997, 2002; Santos et al. 2005; Quirino 2006; Lima 2007; Amorim et al. 2009; Guedes et al. 2009; Araújo et al. 2011; Sobrinho et al. 2013).

Analyses of the phenological profiles of the caatinga species have demonstrated strong seasonal characteristics in most species, with their flowering and fruiting periods generally preceding leaf flush after the start of the rainy season (Machado et al. 1997)-indicating a direct relationship with seasonal variations in the water status of those plantswhich, in turn, reflects the soil-water availability in association with biotic factors, including leaf structure and longevity, leaf fall, the depth and density of their root systems, wood densities, and the photochemical efficiencies of photosystem II (Borchert 1994; Borchert et al. 2004; Singh \& Kushwaha 2005; Lima 2007; Trovão et al. 2007).

These analyzed the adaptive strategies and phenological behaviors of two populations of Cnidoscolus quercifolius Pohl growing in caatinga areas in the western Seridó microregion of the Paraiba state, Brazil, in relation to variations in rainfall and the physiological factors of water potential and photosynthetic efficiency in individuals of that species.

\section{Material and Methods}

The present study was undertaken in the municipalities of Santa Luzia (6 $6^{\circ} 52^{\prime} 19^{\prime \prime} \mathrm{S} \times$ $\left.36^{\circ} 55^{\prime} 08^{\prime \prime} \mathrm{W}\right)$ and São Mamede $\left(6^{\circ} 55^{\prime} 19^{\prime \prime} \mathrm{S} \times\right.$ $\left.37^{\circ} 05^{\prime} 45^{\prime \prime} \mathrm{W}\right)$ in the tropical semiarid western Seridó micro-region of the Paraíba state,
Northeastern Brazil. Regional temperatures vary between 25 and $30{ }^{\circ} \mathrm{C}$, with the average annual rainfall of approximately $550 \mathrm{~mm}$ concentrated between January and April (although there can be many periods of abundant rainfall or extended droughts). The western Seridó region of the Paraíba State has a hot semiarid climate (classified as BSw'h according to the Koppen system) (Oliveira et al. 2014). Monthly phenological observations of the vegetative phenophases of leaf flushing and leaf fall were made, and the reproductive phenophases of flowering and fruiting of two populations of $C$. quercifolius located in Santa Luzia (Yayu Farm) and São Mamede (Promissão Farm) during both the rainy and dry seasons during the period between March 2009 and February 2011.

Rainfall measurements were collected AESA-PB between 2009 and 2011, these data were presented and associated with the phenological events. Analysis of the quantum efficiency were performed with a fluorescence detector PEA(Plant Efficiency Analyzer) determining $\mathrm{F}_{0}$ (minimal or initial fluorescence), Fv (increase fluorescence from $\mathrm{F}_{0}$ to $\mathrm{Fm}$ ), $\mathrm{Fm}$ (maximum fluorescence), and $\mathrm{Fv} / \mathrm{Fm}$ ratio that allows the quantum yield determination of the photochemical phase of photosynthesis. Stems with $10 \mathrm{~cm}$ were removed from plants and placed in a Scholander pressure chamber, and the reading being taken after the first liquid expulsion from the cut (Oliveira et al. 2014).

The definitions of the phenophases used here follow Fournier (1974), Morellato (1991), and Morellato et al. (1989), considering the presence or absence of a given phenophase (Fournier 1974) and indicating activity peaks according to Bencke \& Morellato (2002) that allows the Borchert Intensities to be determined (Borchert et al. 2002).

These analyzed all of the flowering adult plants encountered when the fieldwork first began, totaling 21 individuals in the population on the Promissão Farm and 15 individuals on the Yayu Farm. The phenological patterns of these populations were examined in relation to precipitation, plant water potentials, and photosynthetic quantum efficiencies, following Oliveira et al. (2014).

We recorded the initial, peak, and final phases of the phenophase of both leaf flushing and leaf fall. In terms of reproductive stages, we evaluated flowering (the formation of floral buds, flower opening, until the absence of flowers) and fruiting (the initiation of fruiting, young fruits, and mature fruits); the durations of the flowering 
and fruiting periods corresponded to the period between the emergence of the first flower and fruit on any individual until when the last individual in the population was observed displaying either of these phenophases. Analyses of the flowering and fruiting patterns followed the classifications proposed by Newstrom et al. (1994).

Statistical analyses of the data were performed using the Statistica 6.0 software package. The normalities of the phenophase data were verified using the Shapiro-Wilk test, and the Spearman correlation test was used to determine the existence (or not) of correlations between the phenophases and climatic factors. We also estimated the intensities of each phenophase in the tree crowns of individual trees using the methodology proposed by Borchert et al. (2002), which is based on assigning scores (on a scale of 0 to 3 ) to the quantities of leaves in any tree crown, with $0=$ the absence of leaves, $1=$ few leaves $(<33 \%), 2=$ many leaves (33 to $66 \%$ ), and $3=$ abundant leaves $(>66 \%)$, and subsequently calculating the percentages of leaves using the following formula: 100 ( $\sum$ scores $)$ /maximum score. This technique, therefore, analyzes the proportions of leaves by summing the scores $(0,1,2$, and 3$)$ of the individuals in a plant population (multiplied by 100) divided by the maximum value possible for all individuals of that population with abundant leaves (score $=3$ ), according to the methodology described by Lima (2007).

\section{Results}

Leaf flushing demonstrated notable synchrony in the two populations evaluated during the two cycles accompanied between December 2009 and February 2010, with $80 \%$ of the individuals of the Yayu Farm population (Santa Luzia) and $80.95 \%$ of the individuals of the Promissão Farm population (São Mamede), initiating leaf flushing synchronously. During the next cycle of leaf flushing, which occurred between the months of November and December 2010, 100\% of the individuals displayed this phenophase. The periods of greatest leaf flushing were observed in January and November of 2010 (Tabs. 1, 2).

Leaf flushing occurred between the end of the dry season and the transition period just before the rainy season.

Examinations of the water potentials of individual trees in the leaf flushing phase indicated that this phenophase was preceded by very negative water potential values in the Santa Luzia population (-0.82 MPa, Nov/Dec-2009 and -0.97 MPa, Sep/ Oct-2010). During these periods, the average values of photosynthetic quantum efficiency were 0.591 for the Santa Luzia population, leaf fall in this population initiated between the months of JulyAugust/2009 and from June-October/2010 (Fig. 1).

A significant negative correlation was observed between the phenophase of leaf flushing and rainfall volume for the period just before this phenological event $\left(r_{s}=-0.54 p<0.05\right)$ in the populations examined.

The activity index indicated that leaf flushing peaked in January and November 2010, and demonstrated the synchrony of this phenological event within the population. The analyses of intensity indicated that when this phenological

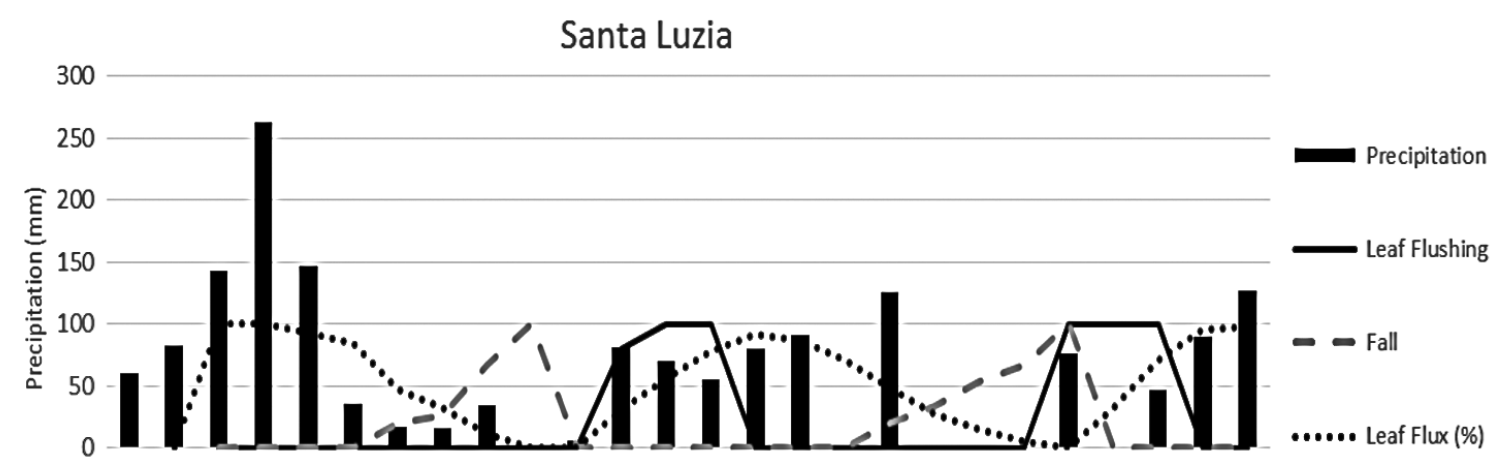

jan feb mar apr may jun jul aug sep oct nov dec jan feb mar apr may jun jul aug sep oct nov dec jan feb

2009-2011 (Years)

Figure 1 - Precipitation and the phenological events of leaf flushing, leaf fall and the Borchert Intensity percentage (proportions of leaves) in Cnidoscolus quercifolius between March/2009 and February/2011 in areas of caatinga vegetation in the municipality of Santa Luzia, Paraíba state, Brazil. 
Table 1 - Percentages of phenological events and leaves in the crowns of individuals trees in the population of Cnidoscolus quercifolius on the Yayu Farm, municipality of Santa Luzia, Paraíba state, Brazil, between March/2009 and February/2011.

\begin{tabular}{|c|c|c|c|c|c|}
\hline Months/phenological events & Average $\%$ of leaves & Leaf flushing & Leaf fall & Flowering & Fruiting \\
\hline March - 2009 & 100.00 & 0 & 0 & 100.00 & 100.00 \\
\hline April & 100.00 & 0 & 0 & 86.67 & 100.00 \\
\hline May & 93.36 & 0 & 0 & 0 & 86.67 \\
\hline June & 84.80 & 0 & 0 & 0 & 46.67 \\
\hline July & 47.73 & 0 & 20.00 & 0 & 0 \\
\hline August & 32.52 & 0 & 26.67 & 0 & 0 \\
\hline September & 11.01 & 0 & 66.67 & 0 & 0 \\
\hline October & 0 & 0 & 100.00 & 0 & 0 \\
\hline November & 0 & 0 & 0 & 0 & 0 \\
\hline December & 30.60 & 80.00 & 0 & 0 & 0 \\
\hline January -2010 & 56.47 & 100.00 & 0 & 20.00 & 20.00 \\
\hline February & 78.23 & 100.00 & 0 & 40.00 & 40.00 \\
\hline March & 91.35 & 0 & 0 & 80.00 & 80.00 \\
\hline April & 86.64 & 0 & 0 & 40.00 & 80.00 \\
\hline May & 70.17 & 0 & 0 & 0 & 80.00 \\
\hline June & 48.57 & 0 & 20.00 & 0 & 60.00 \\
\hline July & 27.90 & 0 & 33.33 & 0 & 13.33 \\
\hline August & 15.30 & 0 & 53.33 & 0 & 13.33 \\
\hline September & 5.04 & 0 & 66.67 & 0 & 6.67 \\
\hline October & 0 & 0 & 100.00 & 0 & 0 \\
\hline November & 32.02 & 100.00 & 0 & 0 & 0 \\
\hline December & 70.84 & 100.00 & 0 & 100.00 & 0 \\
\hline January - 2011 & 94.87 & 0 & 0 & 100.00 & 73.30 \\
\hline February & 98.41 & 0 & 0 & 100.00 & 100.00 \\
\hline
\end{tabular}

event was intense during the study period (from March-June/2009 and February-April/2010) it occurred in greater leaf cover individuals studied (Fig. 1).

The first complete flowering cycle observed during the present study occurred between January/ April 2010, four months; the peak of flowering activity occurred in March 2010 with high degrees of synchrony within the two populations (Tabs. 1,2).

Flowering occurred in both populations during the rainy season, with the flowering peak less negative water potential values $(-0.41 \mathrm{MPa})$ in the Santa Luzia population March and April 2010 (Fig. 2). The recorded values of the photosynthetic quantum efficiency of photosystem II during this period indicated that the individuals were not stressed and demonstrated optimal photochemical efficiency (0.751 MPa).

Fruiting occurred in parallel flowering during the rainy season and continued for 4 to 5 months in 2009, with activity between March and April 2009 (Fig. 2).

The São Mamede population also initiates the leaf flushing phase at the end of the dry season and the beginning of the rainy season, with indices of very negative water potential between the individuals analyzed (-0.74 MPa, Nov/Dec 2009 and $-0.97 \mathrm{MPa}$, Sep/Oct 2010), confirming 
Table 2 - Percentages of phenological events and leaves in the crowns of individuals trees in the population of Cnidoscolus quercifolius on the Promissão Farm, municipality of São Mamede, Paraíba state, Brazil, during the period between March/2009 and February/2011.

\begin{tabular}{cccccc}
\hline Months/phenological events & Average \% of leaves & Leaf flushing & Leaf fall & Flowering & Fruiting \\
\hline March - 2009 & 100.00 & 0 & 0 & 100.00 & 100.00 \\
April & 100.00 & 0 & 0 & 66.67 & 90.48 \\
May & 87.64 & 0 & 0 & 4.76 & 76.19 \\
June & 71.32 & 0 & 0 & 4.76 & 42.86 \\
July & 37.45 & 0 & 28.57 & 4.76 & 28.57 \\
August & 22.00 & 0 & 38.10 & 4.76 & 4.76 \\
September & 10.38 & 0 & 61.90 & 0 & 4.76 \\
October & 1.24 & 0 & 90.48 & 0 & 0 \\
November & 1.24 & 0 & 90.48 & 0 & 0 \\
December & 32.57 & 80.95 & 0 & 0 & 0 \\
January - 2010 & 62.55 & 100.00 & 0 & 19.05 & 19.05 \\
February & 84.24 & 100.00 & 0 & 33.33 & 33.33 \\
March & 87.15 & 0 & 0 & 85.71 & 85.71 \\
April & 81.40 & 0 & 0 & 76.19 & 76.19 \\
May & 66.81 & 0 & 0 & 0 & 47.62 \\
June & 49.13 & 0 & 19.05 & 0 & 47.62 \\
July & 31.64 & $4.76^{*}$ & 33.33 & $4.76^{*}$ & 42.86 \\
August & 18.11 & $4.76^{*}$ & 52.38 & $4.76^{*}$ & 23.81 \\
September & 5.62 & 0 & 80.95 & 0 & 4.76 \\
October & 0.93 & 0 & 95.24 & 0 & 4.76 \\
November & 36.90 & 100.00 & 0 & 0 & 0 \\
December & 71.01 & 100.00 & 0 & 100.00 & 4.76 \\
January-2011 & 95.18 & 0 & 0 & 100.00 & 100.00 \\
February & 100.00 & 0 & 0 & 100.00 & 100.00 \\
\hline
\end{tabular}

* Highlight for budding, flowering and fruiting of a single individual in the population

that these plants initiated leaf flushing while demonstrating high water deficits. Leaf fall occurs between the months of July-November/2009 and June-October/2010 for the São Mamede population (Fig. 3), during these periods the average values of photosynthetic quantum efficiency were 0.667 for this population.

This phenophase lasted from 4 to 5 months, with peak phases occurring in October 2009 (Tabs. 1, 2), having initiated at the end of the rainy season and beginning of the dry season. Leaf fall was observed to be directly related to the water status of the plant and with photosynthetic quantum efficiency, as leaf fall intensity increased with decreasing plant water potentials. No significant correlation was observed between precipitation and leaf fall at a 5\% level of probability according to the Spearman correlation coefficient.

Flowering and fruiting in the São Mamede population occurs in the rainy season (Fig. 4), with the peak of phenophase in March 2009 and 2010, individuals in the population optimal photochemical efficiency of the $0.812 \mathrm{MPa}$.

No significant correlation was observed between precipitation values and flowering by the 

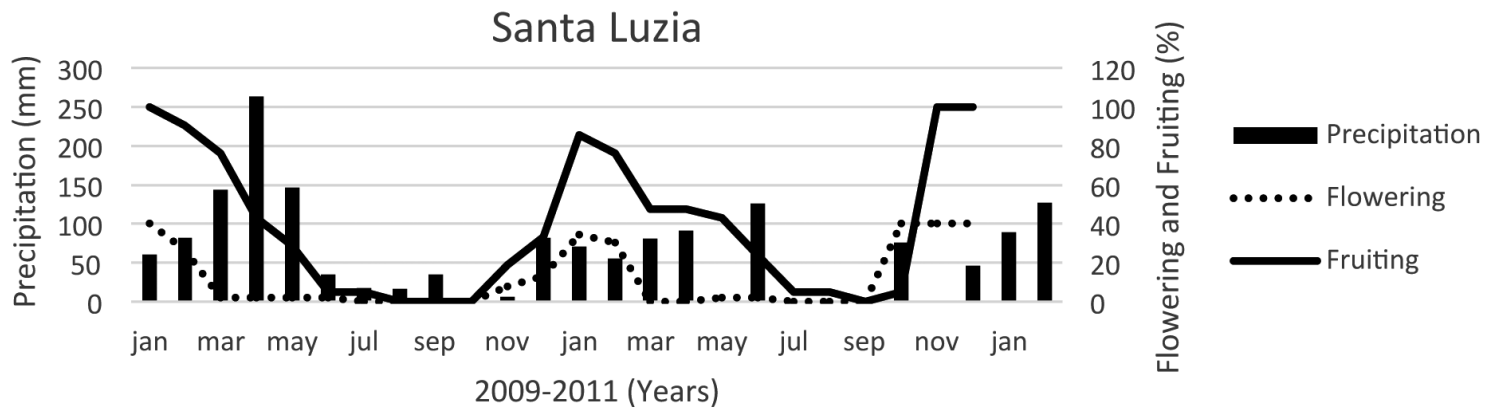

Figure 2 - Precipitation and the phenological events of flowering and fruiting in Cnidoscolus quercifolius between March/2009 and February/2011, in an area of caatinga vegetation in the municipality of Santa Luzia, Paraíba state, Brazil.

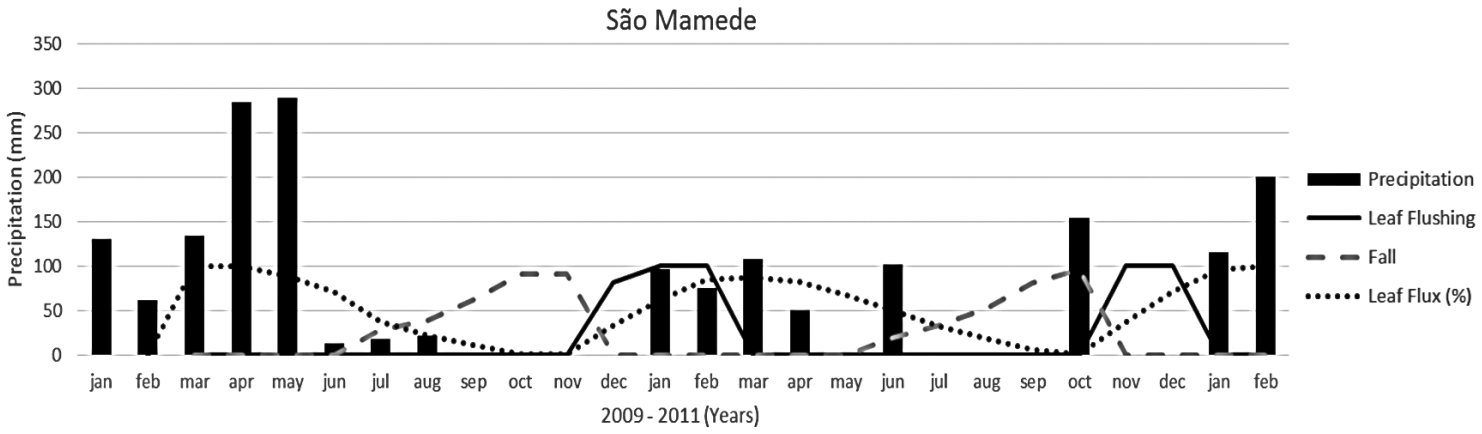

Figure 3 - Precipitation and the phenological events of leaf flushing, leaf fall and the Borchert Intensity percentage (proportions of leaves) in Cnidoscolus quercifolius between March/2009 and February/2011 in areas of caatinga vegetation in the municipality of São Mamede, Paraíba state, Brazil.

Spearman correlation coefficient, at a 5\% level of probability.

During the year 2010, fruiting continued for approximately 8 months, with a peak between March-May of that same year (Fig. 4). The phenophase of fruiting demonstrated a significant positive correlation with rainfall $\left(\mathrm{r}_{\mathrm{s}}=0.56 ; \mathrm{p}=0.004\right)$.

The periods of both flowering and fruiting demonstrated variations related to the water potentials and photosynthetic quantum efficiencies of the plants, as the peaks of these phenophases were associated with less negative water potential values and higher average values of photosynthetic quantum efficiency (between 0.75 and 0.85 ).

\section{Discussion}

Leaf flushing occurred at the end of the dry season and during the transition period into the rainy season in the present study, corroborating other studies of the phenological patterns of shrub-arboreal vegetations in arid and semiarid regions (Borchert 1994; Chapotin et al. 2006; Quirino 2006; Lima 2007). Although leaf flushing occurred during the seasonal dry period, the leaves of all the individuals of both populations examined attained maximum blade expansion only during the rainy season. Individuals of the populations examined here were at their points of maximum deciduousness immediately before leaf flushing-an important strategy for water economy, allowing the continuity of phenological events that would culminate in flowering.

The significant negative correlation of the leaf flushing phenophase observed in the present work differed from the results in other woody caatinga species in the Seridó region of Rio Grande do Norte state, Brazil, which presented a strong correlation between rainfall indices and leaf formation (Amorim et al. 2009). However, Souza et al. (2012) in research with the species Senna cana (Nees \& Mart.) H.S. Irwin \& Barnely in the Chapada da Diamantina - BA, observed a 


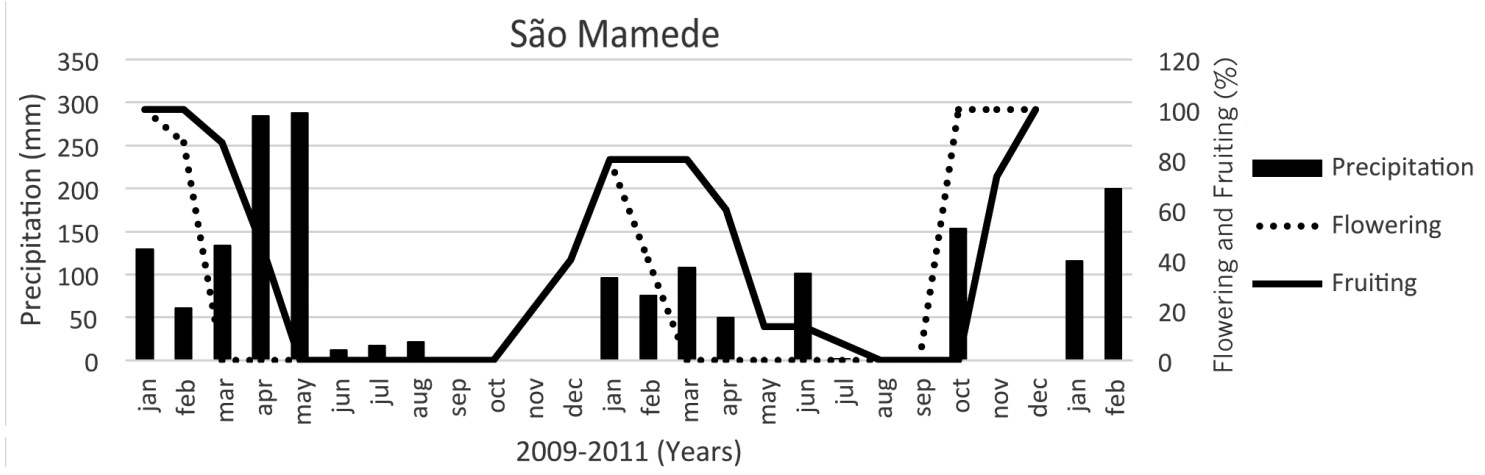

Figure 4- Precipitation and the phenological events of flowering and fruiting in Cnidoscolus quercifolius between March/2009 and February/2011, an area of caatinga vegetation in the municipality of São Mamede, Paraíba state, Brazil.

low correlation between the phenology of budding and the rainy season.

The phenological events of plants growing in tropical climates are determined by the duration and intensity of the dry season (Mooney et al. 1995). The study of $C$. quercifolius indicated that there was no large temporal separation of the phenophases of leaf flushing and flowering, as the plants flowered when leaf flushing terminated, a physiological mechanism of resistance to semiarid conditions, that usually experiences only a short and often irregular rainy period (between January and June). Reproductive events in the dry tropics generally occur during periods of low photosynthetic activity or after periods of high reserve accumulation (Fenner 1998).

In a research project examining woody plants in caatinga regions in Pernambuco State, noted that most of species that replaced their leaves during the dry season had low wood densities supporting the observation that they can store greater quantities of water in their trunks, as reported by Lima (2007). However, our studies in the Seridó region of Paraiba State demonstrated very negative water potential levels in the branches of C. quercifolius directly preceding leaf flushing. The values of water potential only became less negative after the beginning of the rainy season, as was expected, during which time the individuals of the two populations were in their final phases of leaf flushing and beginning of leaf blade expansion.

The maximum leaf fall activity was observed during the dry season, in agreement with other published results of phenological studies of woody caatinga plants (Lima 2007; Amorim et al. 2009).

The leafless period of woody plants generally occurs in response to water stress conditions and represents that portion of their annual cycle in which resources (such as light, water, and nutrients) are not being consumed, or only consumed at very low intensities (Kushwaha \& Singh 2005). These authors also noted that the fully deciduous period is an available indicator of drought experienced severe water stress conditions reflecting the integrated effects of seasonal dryness, morpho-functional characteristics of the plants, and the levels of soil humidity; they also stated that leaf fall has a determinate role in initiating flowering.

The species $C$. quercifolius is typically deciduous at the peak of the dry season and experiences increasingly intense water limitations as the dry season advances-culminating in leaf abscission as a strategy for reducing its maintenance metabolic levels in preparation for the dynamics of upcoming phenological events of leaf flushing at the end of the dry season followed by flowering.

Fluorescence studies of the quantum efficiency of photosystem II represent an important tool for studying plant water stress in plants that demonstrated quantum efficiency values between 0.75 and 0.85 . Under non-stress conditions, (Krause \& Weiss 1991; Maxwell \& Johnson 2000), these values were seen in $C$. quercifolius during the rainy period. Lower values indicated water stress, reductions of the maximum quantum efficiencies of photosystem II, and the possibility of damage to the plant's photosynthetic apparatus.

Flowering and fruiting in C. quercifolius occurred during the rainy season when plant water potentials were less negative and quantum efficiency values were between 0.751 and 0.812 , corresponding to the maximum efficiency of light energy in that photochemical process and directly reflecting the physiological states of the plants, 
with high metabolic activity levels and the equally high energetic demands of the phenophases of flowering and fruit development and maturation. The highest peaks of flowering and fruiting in these plants were observed during the rainy season, with flowering closely following the period of leaf flushing and leaf blade expansion. Fruiting, on the other hand, continued for a longer period of time, extending into the phenophase of leaf fall, similar to the results reported by Lima (2007); Amorim et al. (2009), and Araújo et al. (2011), in other plant communities in the caatinga a determinant factor in plant reproduction in tropical regions, especially in tropical dry forests (Griz \& Machado 2001). The phenophases of flowering and fruiting were observed to have annual patterns in C. quercifolius in this study and for the period in which it developed.

\section{Conclusion}

The species Cnidoscolus quercifolius presents seasonality in relation to the climatic variations of precipitation and the analyzed ecophysiological variables, water potential, and photochemical quantum efficiency of photosystem II, for the phenotypes of budding, falling, flowering, and fruiting. Rainfall negatively influences budding, which occurs at the end of the dry period and early rainy season. Leaf fall was not significantly influenced by precipitation; however, it showed a direct relationship with the water deficit and photochemical efficiency of photosystem II, for the dry season. Flowering occurred shortly after the outbreak with peak activity in March 2010, during the rainy season.

\section{References}

Amorim IL, Sampaio EVSB \& Araújo EL (2009) Fenologia de espécies lenhosas da caatinga do Seridó, RN. Revista Árvore 33: 491-499.

Araújo LDA, Quirino ZGM \& Machado IC (2011) Fenologia reprodutiva, biologia floral e polinização de Allamanda blanchetti uma Apocynaceae endêmica da Caatinga. Revista Brasileira de Botânica 34: 211-222.

Barbosa DCA, Alves JL, Prazeres SM \& Paiva AMA (1989) Dados fenológicos de 10 espécies arbóreas de uma área de caatinga (Alagoinha - PE). Acta Botanica Brasilica 3: 109-117.

Barbosa DCA, Barbosa MCA \& Lima LCM (2003) Fenologia de espécies lenhosas da caatinga. In: Leal IR, Tabarelli M \& Silva JMC (orgs.) Ecologia e conservação da caatinga. Editora Universitária UFPE, Recife. Pp. 657-693.
Bencke CSC \& Morellato LPC (2002) Comparação de dois métodos de avaliação da fenologia de plantas, sua interpretação e representação. Revista Brasileira de Botânica 25: 269-275.

Borchert R (1994) Soil and stem water storage determine phenology and distribution of tropical dry forest trees. Ecology 75: 1437-1449.

Borchert R, Rivera G \& Hagnauer W (2002) Modification of vegetative phenology in a tropical semideciduous forest by abnormal drought and rain. Biotropica 34: 27-39.

Borchert R, Meyer SA, Felger RS \& Porter-Bolland L (2004) Environmental control of flowering periodicity in Costa Rican and Mexican tropical dry forests. Global Ecology Biogeography 13: 409-425.

Chapotin SM, Razanameharizaka JH \& Holbrook M (2006) Baobab trees (Adansonia) in Madagascar use stored water to flush new leaves but not support stomatal opening before the rain season. New Phytology 169: 549-559.

Fenner M (1998) The phenology of growth and reproduction in plants. Perspectives in Plant Evolution Systematics 1: 78-91.

Fournier LA (1974) Um método cuantitativo para la medición de características fenológicas en arboles tropicales. Turrialba 24: 422-423.

Guedes RS, Quirino ZGM \& Gonçalves EP (2009) Fenologia reprodutiva e biologia da polinização de Canavalia brasiliensis Mart ex Benth. (Fabaceae), em área de caatinga. Revista Biotemas 22: 27-37.

Griz LMS \& Machado ICS (2001) Fruiting phenology and seed dispersal syndromes in caatinga, a tropical dry forest in the northeast of Brazil. Journal of Tropical Ecology 17: 303-321.

Krause GH \& Weiss E (1991) Chlorophyll fluorescence and photosynthesis. Annual Review of Plant Physiology and Plant Molecular Biology 4: 313-359.

Kushwaha, CP \& Singh, KP (2005) Emerging paradigms of tree phenology in dry tropics. Current Science 89: 964-975.

Lima ALA(2007) Padrões fenológicos de espécies lenhosas e cactaceas em uma área do semiárido do Nordeste do Brasil. Dissertação de Mestrado. Universidade Federal Rural de Pernambuco, Recife. 84p.

Locatelli E \& Machado IC (1999a) Comparative study of the floral biology in two ornithophilous species of Cactaceae: Melocactus zehntneri and Opuntia palmadora. Bradleya 17: 75-85.

Locatelli E \& Machado IC (1999b) Floral biology of Cereus pernambucensis: a sphingophilous cactus of restinga. Bradleya 17: 86-94.

Machado IC, Barros LM \& Sampaio EVSB (1997) Phenology of caatinga species at Serra Talhada, PE, Northeastern Brazil. Biotropica 29: 57-68.

Machado ICS, Vogel S \& Lopes AV (2002) Pollination of Angelonia cornigera Hook. (Scrophulariacaea) 
by long legged oil collecting bees in NE - Brazil. Plant Biology 4: 352-359.

Maxwell K \& Johnson G(2000) Chlorophyll fluorescence-a pratical guide. Journal of Experimental Botany 51: 659-668.

Mooney HA, Medina E \& Bullock SH (1995) Neotropical deciduous forest. In: Bullock SH, Mooney HA \& Medina E (eds.) Seasonally Dry Tropical Forest. Cambridge Academic Press, New York. Pp. 221-242.

Morellato LPC, Rodrigues RR, Leitão-Filho HF \& Joly CA (1989) Estudo comparativo de fenologia de espécies arbóreas de floresta de altitude e floresta mesófila semidecídua na Serra do Japi, Jundiaí, SP. Revista Brasileira de Botânica 12: 85-98.

Morellato LPC (1991) Estudo da fenologia de árvores, arbustos e lianas de uma floresta semidecídua no sudeste do Brasil. Tese de Doutorado. Universidade Estadual de Campinas, Campinas. 176p.

Newstrom LE, Frankie GW \& Baker HG (1994) A new classification for plant phenology based on flowering patterns in lowland tropical rain forest trees at $\mathrm{La}$ Selva, Costa Rica. Biotropica 26: 141-159.

Oliveira ECS, Costa Júnior EO, Fernandes PD \& Trajano EVA (2014) Photochemical efficiency of photosystem II (PSII) and water potencial of Cnidoscolus quercifolius Pohl in áreas of caatinga paraibana. Iheringia 69: 479-487.

Pereira RMA, Araújo-Filho JA, Lima RV, Lima FDG \& Araújo ZB (1989) Estudos fenológicos de algumas espécies lenhosas e herbáceas da caatinga. Ciência Agronômica 20: 11-20.

Quirino ZGM \& Machado ICS (2001) Biologia da polinização e da reprodução de três espécies de Combretum Loefl. (Combretaceae). Revista Brasileira de Botânica 24: 181-193.
Quirino ZGM (2006) Fenologia reprodutiva e aspectos ecológicos de cinco espécies simpátricas de cactaceae no cariri paraibano, Nordeste do Brasil. Tese de Doutorado. Universidade Federal de Pernambuco, Recife. 146p.

Santos MJL, Machado IC \& Lopes AV (2005) Fenologia, biologia reprodutiva e diversidade de polinizadores de duas espécies de Jatropha L. (Euphorbiaceae), em caatinga, Nordeste do Brasil. Revista Brasileira de Botânica 28: 361-373.

Singh KP \& Kushwaha CP (2005) Diversity of flowering and fruiting phenology of trees in a tropical deciduous forest in India. Annals of Botany 97: 265-276.

Sobrinho MS, Tabatinga GM, Machado IC \& Lopes AV (2013) Reprodutive phenological pattern of Calotropis procera (Apocynaceae) an invasive species in Brazil: annual in native areas; continuous in invaded areas of caatinga. Acta Botanica Brasilica 27: 456-459.

Souza IM, Coutinho K \& Funch LS (2012) Estratégias fenológicas de Senna cana (Nees \& Mart.) H.S. Irwin \& Barnely (Fabaceae: Caesalpinoideae) como mecanismo eficiente para atração de polinizadores. Acta Botanica Brasilica 26: 435-443.

Trovão DMBM, Fernandes PD, Andrade LA \& Dantas Neto J (2007) Variações sazonais de aspectos fisiológicos de espécies da Caatinga. Revista Brasileira de Engenharia Agrícola e Ambiental 11: 307-311.

Vogel S \& Machado ICS (1991) Pollination of four sympatric species of Angelonia (Scrophulariaceae) by oil-collecting bees in NE, Brazil. Plant Systematics Evolution 178: 78-153. 